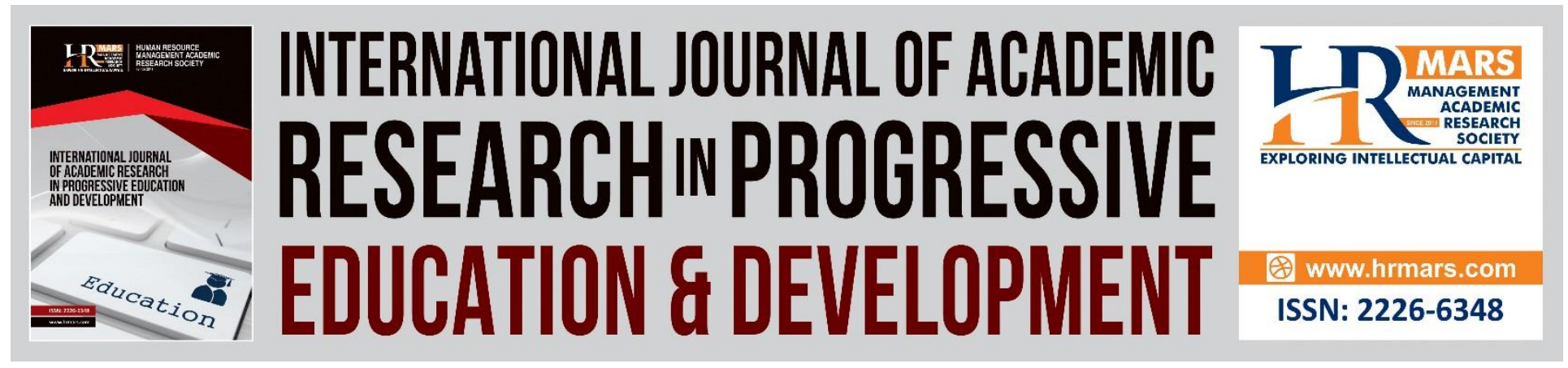

\title{
Relationship between Malay Language Writing Skills and Learning Motivation among Non-Native Speakers
}

Rozita Radhiah Said, Nor'azian Nahar, Norazlina Mohd Kiram

To Link this Article: http://dx.doi.org/10.6007/IJARPED/v8-i4/6639

DOI:10.6007/IJARPED/v8-i4/6639

Received: 15 October 2019, Revised: 30 October 2019, Accepted: 11 November 2019

Published Online: 30 November 2019

In-Text Citation: (Said, Nahar, \& Kiram, 2019)

To Cite this Article: Said, R. R., Nahar, N., Kiram, N. M., (2019). Relationship between Malay Language Writing Skills and Learning Motivation among Non-Native Speakers. International Journal of Academic Research in Progressive Education and Development, 8(4), 566-580.

Copyright: (C) 2019 The Author(s)

Published by Human Resource Management Academic Research Society (www.hrmars.com)

This article is published under the Creative Commons Attribution (CC BY 4.0) license. Anyone may reproduce, distribute, translate and create derivative works of this article (for both commercial and non-commercial purposes), subject to full attribution to the original publication and authors. The full terms of this license may be seen

at: http://creativecommons.org/licences/by/4.0/legalcode

\section{Vol. 8(4) 2019, Pg. 566 - 580}

Full Terms \& Conditions of access and use can be found at http://hrmars.com/index.php/pages/detail/publication-ethics 


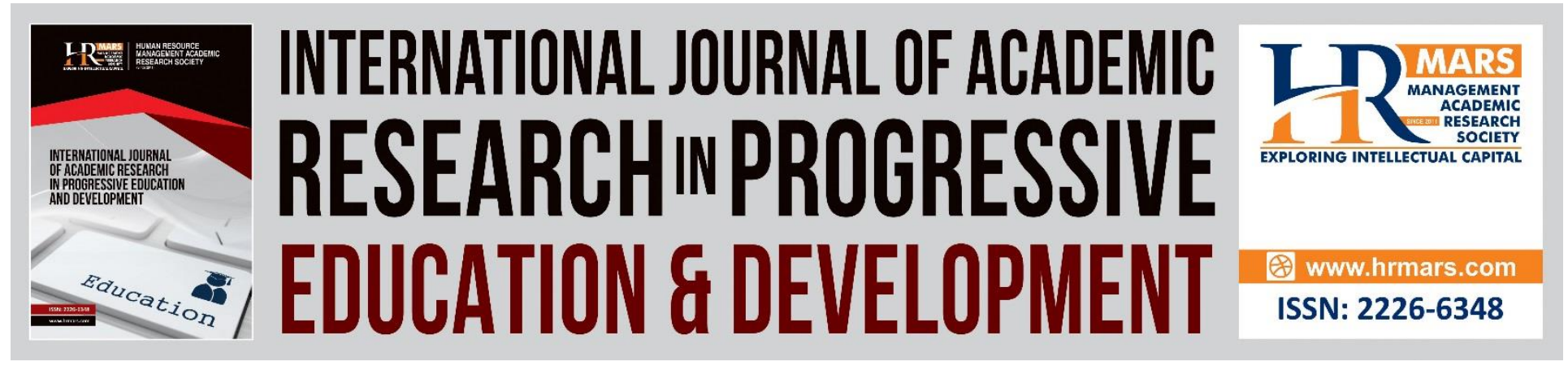

\title{
Relationship between Malay Language Writing Skills and Learning Motivation among Non-Native Speakers
}

\author{
Rozita Radhiah Said, Nor'azian Nahar, Norazlina Mohd Kiram
}

Faculty of Educational Studies, Univesiti Putra Malaysia

\begin{abstract}
The study was carried out to determine the relationship between Malay language (BM) writing skills and learning motivation among non-native speakers. A total of 414 research participants from 5 Chinese National-type primary schools (SJKC) and Tamil National-type primary schools (SJKT) in the district of Kuantan were selected for the study. Two instruments were developed which were a questionnaire to gauge learner motivation and a writing skill proficiency test for BM at primary school level (UPBM_SR). The study adopted a cross-sectional research design. Data was analysed using IBMSPSS version 23. Results from the writing test show that a majority of respondents achieved Level 1 (Very Minimal) at 25.1\% (104 respondents), followed by Level 3 (Limited) at 20.3\% (84 respondents), Level 2 (Minimal) at 19.8\% (82 respondents), Level 4 (Fairly Skilful) at 14.5\% (60 respondents), Level 5 (Almost Skilful) at 10.1\% (42 respondents), Level 6 (Skilful) at 7.2\% (30 respondents), and Level 7 (Skilful) at 2.9\% (12 respondents). No respondents achieved Level 8 (Highly Skilful). The mean score for instrumental learning motivation was significant with $r(412)=0.22, p<.001$ and the mean score for integrative learning motivation was also significant with $r(412)=0.18, p<.001$. Based on Cohen's (1998) interpretation, the relationship shown is small. Results of the linear regression $(\beta=.20, p<.01)$ show that writing ability is not the main factor affecting the overall score of UPBM_SR. It is hoped that the findings of the study could enhance the knowledge of BM teachers in National-type schools across Malaysia. It is also hoped that the UPBM_SR instrument could be used to develop the BM proficiency of non-native speakers in primary schools in preparation for writing tests at higher levels of schooling.
\end{abstract}

Keywords: Malay Language $(\mathrm{Bm})$ Proficiency, Non-Native Speakers, Chinese National-Type Schools, Tamil National-Type Schools, Writing Skills

\section{Introduction}

Language communication is a necessity for every individual. The communication process of receiving and producing language is carried out daily whether in the native language (L1) or second language (L2). Language proficiency in the L2 can be enhanced when the L2 is used for communication. To achieve fluency in the $L 2$, it has to be practiced since early childhood so that 


\section{INTERNATIONAL JOURNAL OF ACADEMIC RESEARCH IN PROGRESSIVE EDUCATION AND}

DEVELOPMENT

Vol. 8, No. 4, 2019, E-ISSN: 2226-6348 @ 2019 HRMARS

using the language becomes automatised. This is important as BM is the language of knowledge, unity, and it is the official language in Malaysia. The process of using the BM as the L2 does not happen naturally, instead the language has to be learnt, especially in the aspect of writing skills (Mohamad Zuki KN., 2017). Writing ability and especially, essay writing is said to require the highest skills, as using thinking tools and writing essays are endeavours that have to be mastered with hard work, especially for L2 speakers of the language (Sariyan, 2011).

\section{Statement of the Problem}

Based on Table 1, the School Cumulative Grade (GPS) for the Primary School Performance Test (UPSR) for the SJKC in the district of Kuantan from 2012 to 2014, showed a decrease. In 2014, both SJKC and SJKT recorded decrements in the GPS for the Writing section of the BM UPSR examination.

Table 1: Results of the UPSR Examination for the district of Kuantan in 2012, 2013, dan 2014 for BM- Writing section

\begin{tabular}{cccc}
\hline & Year/School type & \multicolumn{2}{c}{ School Cumulative Grade (GPS) } \\
\hline & $\mathbf{2 0 1 2}$ & BM-Writing & Subject Overall \\
\hline SJKC & & 2.6 & 2.4 \\
\hline & SJKT & 2.9 & 2.3 \\
\hline & & & \\
\hline & 2013 & BM- Writing & Subject Overall \\
\hline SJKC & & 2.5 & 2.4 \\
\hline & SJKT & 2.5 & 2.1 \\
\hline & 2014 & BM- Writing & Subject Overall \\
\hline SJKC & & 3.0 & 2.3 \\
\hline & SJKT & 3.0 & 2.6 \\
\hline
\end{tabular}

(Source: District Education Office of Kuantan, Pahang)

This analysis shows that the level of writing skills for non-native speakers of BM is worrying. The relationship between learner motivation and BM proficiency could not be determined without empirical evidence. To what extent do BM Writing skills, instrumental learning motivation, and integrative learning motivation enhance BM proficiency levels among non-native speakers of $B M$ ? This question requires serious attention as mastery of BM as an L2 especially in writing skills needs to be nurtured from young. Understanding of written input is seen as the only mechanism that results in the development of basic language proficiency (Hamid, 2014).

\section{Research Objectives}

1. Identifying the levels of Malay language writing skills among students who are non-native speakers in the National-type primary schools in the district of Kuantan, Pahang.

2. Identifying the realtionship between writing scores for UPBM_SR and the mean scores of integrative learning motivation and instrumental learning motivation among non-native speakers in the National-type primary schools in the district of Kuantan, Pahang. 
Vol. 8, No. 4, 2019, E-ISSN: 2226-6348 @ 2019 HRMARS

3. Determining the relationship and influence of integrative learning motivation and instrumental learning motivation on BM witing proficiency in UPBM_SR among nonnative speakers in the National-type primary schools in the district of Kuantan, Pahang.

\section{Research Questions}

1. What are the the levels of Malay language writing skills among students who are nonnative speakers in the National-type primary schools in the district of Kuantan, Pahang?

2. (a) Is there a significant relationship between writing scores for UPBM_SR and the mean score of instrumental learning motivation among non-native speakers in the Nationaltype primary schools in the district of Kuantan, Pahang?

(b) Is there a significant relationship between writing scores for UPBM_SR and the mean score of integrative learning motivation among non-native speakers in the National-type primary schools in the district of Kuantan, Pahang?

3. What are the relationship and influence of integrative learning motivation and instrumental learning motivation on BM witing proficiency in UPBM_SR among nonnative speakers in the National-type primary schools in the district of Kuantan, Pahang?

\section{Significance of Research}

Findings from this research could be beneficial to the Ministry of Education (MOE) for future plans related to language testing for $\mathrm{L} 2$ learners of BM. This study could also help contribute to the number of studies that provide data on proficiency testing of BM in Malaysia. This could contribute to efforts to uphold the Malay language so that it is on par with other global languages, with tests that would measure proficiency levels such as the ones for English (IELTS, TOEFL, and TOEIC), TEF for French, JPLT for Japanese language, KPE for Korean language, and UKBI for Indonesian language. UPBM_SR could also be used as one of the instruments for assessing suitability for Malaysian citizenship among foreign children aged 12 and below as the reading and questioning levels are compatible with the Revised Cognitive Domain of Bloom's Taxonomy by Anderson, David, Krathwohl, et.al., (2013). Research such as this could also benefit all readers and act as a spring board for future studies that are related to the Malaysian Education Blueprint (2013-2025).

\section{Limitations of the Study Location and Respondents}

In terms of location, the selection of schools in the urban area was limited to SJKC A to represent SJKC as it has the research subjects required. SJKT B was selected as it was the only SJKT in the urban category in the district of Kuantan. For the rural category, the schools chosen were SJKC C, SJKT D and SJKT E. The research respondents chosen were limited to students who were non-native speakers of BM of Chinese and Indian descent schooling in National-type primary schools in the district of Kuantan, Pahang. A total of 414 respondents were selected based on the population and number of National-type schools (SJK) in the district of Kuantan. A total of 268 respondents were from SJKC and 146 from SJKT. Only students in the upper-primary level under the age of 13 were selected as the research sample. The rationale for selecting 
Vol. 8, No. 4, 2019, E-ISSN: 2226-6348 ㄷ 2019 HRMARS

research subjects among students who are non-native speakers of BM in SJK is because Stephen, Krashen. (1982) opined that students under the age of 13 will acquire the L2 along with the L1. After the age of 14, students would have to learn the language formally in school and the process of mastering the $\mathrm{L} 2$ would be quite challenging.

\section{Malay Language as the Second Language (L2)}

Second language speakers are groups of speakers who use a language that is different from their native language (Ambridge and Lieven, 2011). Native language speakers master knowledge of their language since young and in a natural setting, while the second language speaker usually master knowledge of the L2 through formal education (Brown, 2007), could develop their L2 through various learning activities and reinforcement practice. The $L 2$ is considered as a tool that could be practiced and used for various purposes (Omar, 2013).

\section{Malay Language Proficiency Level}

According to Rahman \& Kiram (2015), proficiency levels in the Malay language can be equated to the level of mastery of skills in the language. The concept of writing skills is that the writer has the skills to produce creative writing in multiple genres using a variety of vocabulary items accurately, using a language system that is accurate in a detailed and consistent manner. The highest score is Level 8 (Very Skilful) with a range of marks of 92-104 as shown in the Appendix. In the context of the current research, level means rating, stage, measure, and achievement obtained by a student in mastering Malay language skills. A level of language mastery is required to measure whether a person has the ability to listen, speak, read and write in a comprehensive manner to fulfil the needs of this century.

\section{Learning Motivation}

Learning motivation is an important component in determining a student's L2 success. The current research focuses on integrative and instrumental motivation. Without learning readiness, learning might not occur. Integrative motivation relates to the student's tendency and interest to determine their $L 2$ learning goals. This factor includes students' positive attitude towards the L2. Instrumental motivation relates to the act of learning a language for certain purposes often limited by time, such as passing an examination or obtaining something practical and concrete through L2 learning, such as social and financial benefits, or status enhancement in society

\section{Literature Review}

Writing skills must be mastered by all students because they have to answer the BM paper in all public examinations in Malaysia (KSSM, 2017). Students who do not have good writing skills often face problems in answering the examination questions. This phenomena would result in low academic achievement. Said, \& Jamian (2012) research on indigenous students' essay writing found worrying results, as many have not mastered the language system, and are not able to combine syllables, clauses, and phrases to form words and sentences in BM. Writing skills cannot be acquired naturally. Students need to master the concepts related to the orthographic and writing system especially for non-native speakers of BM. The main problem identified by Saiful (2012) in his research on lower-primary Indian students in SJKT was that students could not 
distinguish the alphabets. They were very confused by alphabets that are orthographically similar such as n-m, g-p, and c-e, alphabets that are upside-down of each other such as $m-w$ and $n-u$, and alphabets that are mirror-images of each other such as b-d and q-p. There were also respondents who could not combine syllables to form words, and phrases and clauses to form sentences. Most of the respondents did not understand the Malay language structure. Therefore, they arranged words haphazardly without considering the subject and predicate. They also were not able to structure sentences correctly, and did not understand sentence patterns in BM. Thus, the students were not able to apply writing skills in BM. The teaching of BM was often focussed on transfer of knowledge and facts, and recalling for examination purposes only (Peng, 2016). Yusuf (2015) research also found that most Indian students only memorised grammatical facts and sample essays when studying BM. Othman, Y., (2014) posited that the ability to master writing skills through project-based learning should be developed to help learners in the process of writing independently. Mahamod, (2016) stated that though studies on the use of BM learning strategies among Chinese students based on their attitude and language skills have been carried out, research that identifies the levels of writing ability among non-native speakers at SJKC and SJKT is scarce. Writing skills require attention since primary school as it is the most difficult skill to learn compared to oral and reading skills.

According to Stephen Krashen. (1982) in his Affective Filter Hypothesis, students who are highly motivated and students with low anxiety levels have greater chances of mastering an L2, as they are more receptive to learning the $L 2$. Thus, $L 2$ mastery is closely related to learning motivation. For non-native speakers, learning BM as an L2 is a process of learning the principles of a new language. They have to learn new articulation patterns and behaviours as their articulators are accustomed to producing sounds in their mother tongue. They have also developed reading and writing skills in their L1. This results in L1 interference and could cause reverse transfer. Motivation is also a determinant factor in language mastery especially in the L2. The current research was carried out to determine whether non-native speakers are integratively or instrumentally motivated in learning BM as an L2. Findings of Yusoff et al.'s (2008) research showed that there is a significant relationship between learning motivation and achievements in listening skills in Arabic language. Results from a questionnaire and an Arabic language listening test showed that students with high motivation levels would achieve high achievement levels in an L2. This is due to the students' attitude in learning Arabic language and their own desire to enhance their proficiency levels. Students achieved satisfaction and enjoyed the learning experience as they realise the importance of the language in their lives. If a student learns an L2 due to external reasons and outside pressure, learning motivation would be low (Gardner and Lambert, 1972). Findings form Choosri et al's (2011) research on 140 respondents among undergraduates at Hatyai Technical College also found a relationship between motivation and L2 achievement. The instrumental motivation mean scores were higher compared to integrative motivation for students who obtained high scores for English language competency. Proficiency in the English language is important in Thailand for tertiary education and future career prospects. The correlation between motivation and academic achievement was small. Students who obtained high scores in the English language test were more likely to learn English compared to those who obtained low scores. The results are similar to findings in Liu (2015) study that found a positive correlation between learner motivation and English language proficiency. Past research 
Vol. 8, No. 4, 2019, E-ISSN: 2226-6348 @ 2019 HRMARS

has clearly shown that students who performed well in the L2, whether it is the Malay Language, English language or Arabic language, are instrumentally motivated. The current research investigated students' levels of writing ability in BM, and the relationship between writing ability and motivation, as there is a dearth of research in this area.

\section{Methodology}

The current research used quantitative research with a cross-sectional research design (Idris, N., 2013). Data was collected from the sample once at a time. The cross-sectional research design was chosen to enable the data to be collected directly from the research subjects (Creswell, 2008). The cross-sectional research design is often used in educational research (McMillan, J. H.; Schumacher, S., 2010). The reasons are because of its versatility in investigating almost all research problems and questions, and its efficiency as data from different variables could be combined without taking up a lot of time or incurring high costs. Data collection could also be carried out in a short period of time. Also, generalisations could be made as the sample represents a larger population. The research design was divided into 2 phases: Phase 1 involved designing the BM proficiency test (UPBM_SR) and the scoring levels for UPBM_SR to obtain the general proficiency levels of the non-native speakers of BM. Phase 2 involved developing a questionnaire to obtain the students' demographic information, social economic status, learning motivation and academic achievement levels.

\section{Sampling Procedure}

The sampling procedure used systematic random sampling. Sampling was carried out by selecting samples randomly from the population. The researchers obtained a list of all subjects and they had an equal chance of being selected. Samples were selected by including all the $m$ sample from the list. The selection of the first subject was random, the rest were selected based on a pattern of systematic selection. In this procedure, alternate potential research subjects were selected from the list. The total population of non-native speakers in upper-primary level in National-type schools in the district of Kuantan was 3 252. The calculations for data selection were; population $=3252$, required sample $=414$, therefore $k=8$. To select the first subject, one number from 1 to 8 was selected. The researchers selected the number 3 , so the next number was $3+8=11$ (the next numbers were $11+8,19+8,27+8$, and so on).

Formula $=$ Total population $\quad \mathrm{N}=414$ respondents

The respondents comprised of 198 male students (47.1\%) and 222 female students (52.9\%), with a total of 268 Chinese students and 146 Indian students. The low number of students from SJKT is because SJKT are low enrolment schools. The most number of students $(N=334)$ were from year 6 (12 year olds) as they had just sat for the National standardised examination called UPSR. Given the time data collection was carried out, the school administrators requested that the UPBM_SR was administered to the year 6 students while only 61 year 5 students and 27 year 4 students (mostly from SJKT) were respondents in the study. 
Vol. 8, No. 4, 2019, E-ISSN: 2226-6348 C 2019 HRMARS

\section{Research Instruments}

Writing Test

The UPBM_SR writing test was carried out to determine the students' levels of writing ability in producing creative writing in a variety of genres using a wide-range of vocabulary accurately to show both breadth and depth of vocabulary knowledge and use.

Writing Test Component

- It is divided into 2 sections: Section A: sentence construction based on 5 pictures, and section B: writing an essay (between 80 to 120 words).

- Test duration was 60 minutes: 20 minutes for section $A$, and 40 minutes for section $B$.

- Scoring: 40 marks for section $\mathrm{A}$, and 64 marks for section $\mathrm{B}$.

Writing Test Procedure

- Respondents gathered in the hall.

- The teacher distributed the test papers and respondents answered in the answer booklets provided.

- Answer scripts were marked by teachers who were examiners for the BM UPSR using the scoring rubrics for UPBM_SR.

Scoring rubrics for UPBM_SR

The levels for scoring and the scoring rubrics for UPBM_SR were developed by reviewing and adapting existing rubrics. The scoring levels and rubrics for UPBM_SR would determine the nonnative speakers' scores in the UPBM_SR. Thus, the researchers used the scores for the writing component and overall scores of the UPBM_SR to measure the respondents' levels of proficiency in $\mathrm{BM}$, as shown in the Appendix.

\section{Questionnaire}

The questionnaire which consists of Section A (Demographic information) and Section B (Learning motivation) was used as it allowed for quantitative data collection from a large number of respondents. Section $A$ is related to the respondents' personal information. This section was developed by the researchers to obtain information about the respondents' background. Section B consists of 30 items geared towards obtaining information about the respondents' levels of integrative and instrumental motivation. The items in this section are related to elements of friendship, interaction, and understanding which are related to intrinsic motivation. Items related to extrinsic motivation include the desire for academic achievement. As the respondents were non-native speakers in SKJC and SKJT who were not older than 12 years old, they were guided in completing the questionnaire.

\section{Validity of Research Instruments}

The validity measures of the test and questionnaire were carefully carried out to ensure that the levels of achievement, and language skills were accurately graded. A high level of validity could help measure students' true ability in a test (Konting, MM, 2009). Both test and scoring rubrics 
Vol. 8, No. 4, 2019, E-ISSN: 2226-6348 @ 2019 HRMARS

for UPBM_SR were developed through adaptation and adjustments. To ensure face validity and content validity, the research instruments were reviewed by a panel of experts in the relevant areas in the field of education.

\section{Pilot Study}

A total of 40 upper-primary school students were selected to sit for the UPBM_SR and complete the questionnaire. They were selected from among non-native speakers in Year 5 . The reliability level of the UPBM_SR was high after the researchers improved on the writing section of the test and discussed the instrument with the BM teachers teaching in SJK. The reliability level of the questionnaire records a Cronbach Alpha value of 0.7 . The overall value obtained was 0.94 . This shows that the questionnaire was well-constructed, easy to understand, and suitable to be used for the intended respondents.

\section{Research Findings}

The research findings are discussed based on the following research questions.

1. What are the the levels of Malay language writing skills among students who are nonnative speakers in the National-type primary schools in the district of Kuantan, Pahang? A majority of the respondents achieved Level 1 (Very Minimal) at 25.1\% (104 respondents), followed by Level 3 (Limited) at 20.3\% (84 respondents), Level 2 (Minimal) at 19.8\% (82 respondents), Level 4 (Fairly Skilful) at 14.5\% (60 participants), Level 5 (Almost Skilful) at 10.1\% (42 respondents), Level 6 (Skilful) at 7.2\% (30 respondents), and Level 7 (Skilful) at 2.9\% (12 respondents). No respondents achieved Level 8 (Highly Skilful). Table 5 below shows the respondents' levels of writing skills.

Table 5: Respondents' Levels of Writing Skills ( $N=414)$

\begin{tabular}{llcc}
\hline \hline Level & $\begin{array}{c}\text { Number of } \\
\text { responden } \\
\text { ts }(\boldsymbol{n})\end{array}$ & $\begin{array}{c}\text { Percentage } \\
\text { (\%) }\end{array}$ \\
\hline 1 & Very Minimal & 104 & 25.1 \\
2 & Minimal & 82 & 19.8 \\
3 & Limited & 84 & 20.3 \\
4 & Fairly Skilful & 60 & 14.5 \\
5 & Almost Skilful & 42 & 10.1 \\
6 & Skilful & 30 & 7.2 \\
7 & Almost Highly Skilful & 12 & 2.9 \\
8 & Highly Skilful & 0 & 0.0 \\
\hline & Total & 414 & 100.0 \\
\hline
\end{tabular}

The results show that there is dire need for improvements in writing skills among nonnative speakers. The table shows that $65.2 \%$ obtained only levels 1 to 3 . This shows that the students who are non-native speakers still have not mastered BM writing skills. 
2. (a) Is there a significant relationship between writing scores for UPBM_SR and the mean score of instrumental learning motivation among non-native speakers in the Nationaltype primary schools in the district of Kuantan, Pahang?

(b) Is there a significant relationship between writing scores for UPBM_SR and the mean score of integrative learning motivation among non-native speakers in the Nationaltype primary schools in the district of Kuantan, Pahang?

Table 6 below shows the correlation between writing ability scores in UPBM_SR with the learning motivation levels (integrative and instrumental, $N=414$ ) among students who are non-native speakers in the district of Kuantan.

Table 6: Correlation between writing scores and motivation levels

\begin{tabular}{llccc}
\hline \hline Variable & $\mathbf{1}$ & $\mathbf{2}$ & $\mathbf{3}$ \\
\hline 1 & $\begin{array}{l}\text { Writing ability score for } \\
\text { UPBM_SR }\end{array}$ & 1 & & \\
$\begin{array}{l}\text { Integrative motivation mean } \\
\text { score }\end{array}$ & $.18^{* *}$ & 1 & \\
3 & $\begin{array}{l}\text { Instrumental motivation mean } \\
\text { score }\end{array}$ & $.22^{* *}$ & $.88^{* *}$ & 1 \\
\hline \hline
\end{tabular}

**Significant correlation, $\mathrm{p}<.01$.

3. What are the relationship and influence of integrative learning motivation and instrumental learning motivation on BM witing proficiency in UPBM_SR among nonnative speakers in the National-type primary schools in the district of Kuantan, Pahang?

Table 7 shows the factors (integrative learning motivation, instrumental learning motivation, academic achievement in BM-Comprehension and academic achievement in BM-Writing) that affect the overall scores of UPBM_SR among students who are non-native speakers in the district of Kuantan.

Table 7: Beta Value, semi-partial correlation and semi-partial correlation squared

\begin{tabular}{lccc}
\hline Variable & Beta Value $(\boldsymbol{\beta})$ & $\begin{array}{c}\text { Semi-partial } \\
\text { correlation }\end{array}$ & $\begin{array}{c}\text { Semi-partial } \\
\text { correlation } \\
\text { squared (\%) }\end{array}$ \\
\hline $\begin{array}{l}\text { Integrative motivation mean } \\
\text { score }\end{array}$ & -.06 & -.03 & $<.001$ \\
$\begin{array}{l}\text { Instrumental motivation mean } \\
\text { score }\end{array}$ & .05 & .02 & $<.001$ \\
$\begin{array}{l}\text { BM- Comprehension score } \\
\text { BM- Writing score }\end{array}$ & $.50^{*}$ & .32 & $.10(10.2 \%)$ \\
\hline \hline
\end{tabular}

*Significant, $\mathrm{p}<.05$. 


\section{Discussion}

Generally, the level of writing ability among students who are non-native speakers of BM in the district of Kuantan is worrying. Results show that $65.2 \%$ of the students only achieved levels 1 to 3 in the UPBM_SR test. Students displayed limited abilities to write and edit with many inaccuracies. In fact, there were students who could only write two or three words, even though they have been in primary school for 6 years. For the question in Section A of UPBM_SR, which required students to construct sentences based on 5 pictures, most of the students were only able to write short and simple sentences. Vocabulary use was also very limited. Most students could write accurate sentences for the first picture. The second picture showed a person using a zebra crossing. Many students used different words for zebra crossing. The third picture showed the use of a car seatbelt. Many wrote inaccurate sentences as they translated the word seatbelt from English, and some wrote the word in their native language. For Section B, the overall level is satisfactory. They fulfilled the question requirements. Language use was short and simple. However, the ideas were still quite interesting. Sentences were ungrammatical, but content was still relevant. There was generally fair use of vocabulary, with many spelling and punctuation errors. Overall, spelling and punctuation skills were weak. A number of respondents were not able to string words and sentences together. They were also not able to construct sentences with correct use of subject and predicate. In short, the students have not mastered the correct use of sentence patterns. Findings of the study corroborates Haq Hussin, MS., (2012) study with lowerprimary school students as the respondents. He found that the students' main setback in writing is that they could not differentiate small letters from capital letters, they did not recognise the alphabets, they did not understand the information written, and they did not know how to use punctuations in their writing. In the current research, the respondents' lack of mechanical writing skills result in them not being able to construct sentences or put their ideas in writing, and these are important skills for Section B of the test which required them to write essays. Therefore, the students need to master basic writing skills. This is made worse by the students' lack of mastery of reading skills, which resulted in spelling errors in their writing.

Among the critical problems faced by the respondents in the Writing section of UPBM_SR was that they could not expand on their ideas due to limited vocabulary, errors in spelling, grammar, use of inflections, and sentence structures, use of code-mixing and lack of essay writing skills. The essays written by the students, especially from SJKC, were similar to each other, as they appeared to have been memorised by the students. There were also essays that did not address the questions given, as the essays appeared to have been memorised for examination purposes. A student will memorise essays according to different themes, and would regurgitate the memorised essays as deemed fit, sometimes without understanding the requirements of the questions. As a result, the same answers are written by students and even the errors are similar. Another factor identified is lack of reading of books in BM. Students would instead memorise grammatical rules and essays for examination purposes. The $14.5 \%$ of students who obtained Level 4 (Fairly Skilful) were able to construct sentences based on the title given. Vocabulary use, though limited, was generally accurate. The $10.1 \%$ of student who were at Level 5 (Almost Skilful) and $7.2 \%$ at Level 6 (Skilful) were generally able to write sentences based on the topics given. Ideas were generally well-constructed with clear and interesting presentation of ideas. Vocabulary was also suitable, with correct spelling and use of punctuation. Students also showed 
the ability to use correct grammatical forms. Only $2.9 \%$ of the students were at Level 7 (Skilful). Students were able to write essays which fulfilled the requirements of the questions using precise and a variety of vocabulary. In this research, none of the respondents reached Level 8 (Very Skilful).

\section{Proficiency as a Catalyst for Learning Motivation}

The research findings clearly show that students who are non-native speakers of BM are instrumentally motivated. The aim of learning BM is to obtain good scores in examinations and for social acknowledgement. This is proven when the highest mean score $(M=4.39, S D=0.96)$ in the questionnaire item was for the statement "I learn BM to succeed in the UPSR examination". The second highest mean score $(M=3.87)$ was for the statement "I learn BM for my future". The third highest mean score ( $M=3.77)$ was for the statement "I learn BM because it is a compulsory subject". The results are similar to the conclusions made in Khairul 2017, Zamri 2016, Peng C.F., 2016, Liu 2015 and Abdul Rahman 2015 research that students want to master writing skills to fulfil graduation requirements. For integrative motivation, findings of the study show that the highest mean score $(M=3.83, S D=1.24)$ was recorded for the statement "I learn $B M$ to communicate with people of all races in Malaysia". The second highest mean score $(M=3.76)$ was for two statements, "I like learning BM in school" and "I listen attentively when the BM teacher is teaching". The third highest mean score $(M=3.61)$ was for the statement "I ask the teacher if I do not understand". Integrative motivation is influenced by the culture of the target language. This reflects the importance of mastering all four language skills in BM for students who are non-native speakers so that they could interact with people of various races in Malaysia such as the school staff, neighbours and friends. The results are similar to the findings of Chalermporn Choosri and Usa Intharaksa's (2011) study on students learning English as an L2 in Thailand.

\section{Conclusion}

Overall, the research has fulfilled its objectives and answered the research questions. However, there are still many issues related to nan-native speakers' levels of proficiency in BM that can be suggested for future studies. Among the research areas that require further investigation include;

i. identifying factors such as school ethos or culture, and teacher competency in teaching BM in SJK, strategies for the teaching of BM as an L2 among students in Malaysia, innovations in teaching and learning BM, and strategies to enhance BM proficiency;

ii. evaluation of BM proficiency levels, in particular, for the population of primary school students using observation methods to obtain a more accurate and detailed description of language abilities and proficiency levels; and

iii. research with secondary school students, as BM is the national language and it is vital that all Malaysians master the language at the highest levels of proficiency as it would affect lifestyle and communication among the various races in Malaysia 
INTERNATIONAL JOURNAL OF ACADEMIC RESEARCH IN PROGRESSIVE EDUCATION AND

DEVELOPMENT

Vol. 8, No. 4, 2019, E-ISSN: 2226-6348 @ 2019 HRMARS

\section{Corresponding Author}

Rozita Radhiah Said is senior lecture at the Faculty of Educational Studies, Universiti Putra Malaysia, 43400 UPM Serdang, Selangor Darul Ehsan, Malaysia.

Email: radhiahrozita@upm.edu.my

\section{References}

Rahman, A. F., \& Kiram, M. N. (2015). Bahasa Melayu Sebagai bahasa Negara Bangsa: Kepentingan Melaksanakan Ujian Kecekapan Bahasa Melayu. Mahawangsa 2(1): 15-28 (2015).

Choosri, C. \& Intharaksa, U. (2011). Relationship between Motivation and Students' English Learning Achievement: A study of the Second - year vocational certificate level Hatyai Technical College Students. The 3rd International Conference on Humanities and Social Sciences Proceedings Factors Affecting English Language Teaching and Learning. Faculty of Liberal Arts, Prince of Songkla University.

Creswell, J. W. (2008). Research Design: Quantitative, And Mixed Methods Approaches, Sage Publications, University of Nebraska, London.

Gardner, R. C. (1985). Social Psychology and second language learning: The role ofattitudes and motivation. London: Edward Arnold Publishers.

Hamid, Z. (2014). Faktor Persekitaran Sekolah dan Etnik dalam Perancangan dan Pelaksanaan Program Pendidikan Bahasa Melayu di Malaysia. GEOGRAFIA OnlineTM Malaysian Jurnal of Society and Space 10 Issue 5 (99 -109) C 2014, ISSN 2180-2491

Hussin, H. M. S., Rahman, N. H., \& Syahrani, A. (2012). Pengajaran dan Pembelajaran Bahasa Melayu dalam kalangan pelajar Tamil: Kaedah Gabung Bunyi Kata

Idris, N. (2013). Penyelidikan dalam Pendidikan. Shah Alam, Selangor Malaysia. McGraw-Hill Education(Malaysia) Sdn Bhd. msia.mhe@mheduciton.com

Konting, M. M. (2009). Kaedah Penyelidikan Pendidikan. Edisi ke-9. Kuala Lumpur : Dewan Bahasa dan Pustaka.

Liu, Z. (2015). Factors Affecting English Listening and Speaking abilities on non-English major students: taking engineering students as an example. World Transaction on Engineering and Technology Education (C2015WIETE Vol.13,No 4, 2015.

Mahamod, Z. (2016). Sikap dan Motivasi Murid Iban dalam Mempelajari Bahasa Kedua. Jurnal Pendidikan Bahasa Melayu, 1(1): 13-25.

McMillan, J. H. \& Schumacher, S. (2010). Research in Education: Evidence-Based Inquiry. 7th Edition. MyEducationLab Series. Boston: Pearson.

Yusuf, M. N. Z. (2015). Bahasa Antara dalam Pembelajaran Bahasa Melayu Sebagai Bahasa Kedua.Tesis PhD. UPM (FBMK : 2015 Bil 50)

Ministry of Education Malaysia. (2010). Pentaksiran Kemahiran Menulis dalam Kurikulum Standard Sekolah Rendah. Putrajaya: Malaysian Examinations Syndicate.

Ministry of Education Malaysia. (2011). Kurikulum Standard Sekolah Rendah. Dokumen Standard Kurikulum dan Pentaksiran. Bahasa Melayu Sekolah Jenis Kebangsaan. Tahun Empat.

Ministry of Education Malaysia. (2011). Standard Kurikulum Seni Bahasa dalam Kurikulum Standard Sekolah Rendah. Putrajaya: Bahagian Perkembangan Kurikulum. Majlis Peperiksaan 
Vol. 8, No. 4, 2019, E-ISSN: 2226-6348 @ 2019 HRMARS

Malaysia, 1992. Laporan Keputusan Peperiksaan 1991. Kuala Lumpur : Malaysian Examinations Council.

Ministry of Education Malaysia. (2012). Kurikulum Standard Sekolah Rendah. Dokumen Standard Kurikulum dan Pentaksiran. Bahasa Melayu Sekolah Jenis Kebangsaan. Tahun Lima.

Ministry of Education Malaysia. (2013). Kurikulum Standard Sekolah Rendah. Dokumen Standard Kurikulum dan Pentaksiran. Bahasa Melayu Sekolah Jenis Kebangsaan. Tahun Enam.

Ministry of Education Malaysia. (2013-2015). Pelan Pembangunan Pendidikan Malaysia (PPPP) (Pendidikan Prasekolah hingga Lepas Menengah). Kuala Lumpur: Ministry of Education.

Ministry of Education Malaysia. (2016). Pentaksiran Psikometrik Inventori Kecerdasan Pelbagai (IkeP).

Zuki, M. K. N. (2017). Penerimaan bahasa Melayu dalam kalangan pelajar India. Unpublished doctoral thesis. Faculty of Educational Studies, Universiti Putra Malaysia.

Zuki, M. K. N. (2017). Penerimaan Bahasa Melayu Sebagai Bahasa Kedua dalam Kalangan Murid Berbangsa Bajau. International Journal of Humanities and Social Science Invention. ISSN: 2319-7714. www.ijhssi.org//Volume 6 Issue 10//Oktober.2017//PP.01-11

Yusoff, N. M. R., Mahamod, Z., Ghani, A. K. Z. (2008). Motivasi Pembelajaran Kemahiran Mendengar Bahasa Arab dan Hubungannya dengan Pencapaian Pelajar. Jurnal Pendidikan. 33 (2008) 3-18.

Omar, A. (2003). Language and Language Situation in Southeast Asia:With a Focus on Malaysia. Kuala Lumpur: University of Malaya.

Omar, A. (2013). Pengajaran bahasa Melayu untuk Penutur Asing: Kaedah dan Prinsip. Kuala Lumpur: Dewan Bahasa dan Pustaka.

Othman, Y. (2014). Keupayaan Menguasai Kemahiran Menulis Melalui Pembelajarajan Berasaskan Projek dalam Penulisan Berbentuk risalah di Sekolah Rendah. Jurnal Pendidikan Bahasa Melayu -JPBM ISSN: 2180-4842. Vol.4, No.1 (May 2014): 1929

Peng, C. F. (2016). Masalah Pembelajaran Bahasa Melayu Dalam Kalangan Murid Cina Sekolah Rendah. Jurnal Pendidikan Bahasa Melayu -JPBM (Malay Language Education Journal MyLEL).

Said, R. R. \& Jamian, A. R. (2012). Amalan Pengajaran Karangan Guru Cemerlang di dalam bilik Darjah: Kajian Kes Pelbagai Lokasi. Asia Pacific Journal of Educators and Education, Vol.27, 51-68, 2012. Prosiding Seminar Pasca Siswazah Dalam Pendidikan; Unpublished doctoral thesis. Faculty of Educational Studies. Universiti Putra Malaysia.

Sariyan, A. (2011). Pendidikan Bahasa Melayu dalam Pembentukan Jati Diri Bangsa: Pengajaran Seni Bahasa Untuk Penghayatan bahasa kepada Pelajar Asing. Paper presented at the Seminar Bahasa Melayu 2011, organised by Persatuan Pendidikan Bahasa Melayu Malaysia, Jabatan Pendidikan Negeri Terengganu and Dewan Bahasa dan Pustaka Wilayah Timur on 1416 March 2011.

Stephen, D. K. (1982). Second Language Acquisition and Second Language Learning. Oxford: Pergamon Press, 1981. Pp. 151. Studies in Second Language Acquisition, 5(1), 134-136. doi:10.1017/s0272263100004733

Horne, V. A. J. O. (2011). Child Language Acquisition: Contrasting Theoretical Approaches by Ben Ambridge and Elena V. M. Lieven. International Journal of Language \& Communication Disorders, 47(1), 112-114. doi:10.1111/j.1460-6984.2011.00086.x 
INTERNATIONAL JOURNAL OF ACADEMIC RESEARCH IN PROGRESSIVE EDUCATION AND

DEVELOPMENT

Vol. 8, No. 4, 2019, E-ISSN: 2226-6348 @ 2019 HRMARS

Anderson, W., David, R.. Krathwohl, Peter, W., Airasian, Kathleen, A., Cruikshank, Richard, E., Mayer, Paul, R., Pintrich, J. R., \& Merlin C. W. (2013). A Taxonomy for Learning, Teaching, and Assessing: A Revision of Bloom's Taxonomy of Educational Objectives, Abridged Edition Lorin 9781292042848 • (C2013 336pp 